Saparuddin *)

Universitas Negeri Makassar

Dian Dwi Putri Ulan Sari

Patongai

Universitas Negeri Makassar

Sahribulan

Universitas Negeri Makassar

\section{HUBUNGAN ANTARA KEMAMPUAN BERPIKIR KRITIS DAN HASIL BELAJAR PESERTA DIDIK MELALUI PENERAPAN MODEL PEMBELAJARAN BERBASIS MASALAH}

Abstrak: Penelitian ini bertujuan untuk mengetahui hubungan antara kemampuan berpikir kritis dengan hasil belajar biologi peserta didik. Jenis Penelitian ini adalah penelitian pra eksperimen (pre-experimental design) dan korelasi dengan rancangan One Group Pretest-Posttest design. Sampel penelitian terdiri dari satu kelas yaitu kelas XI IPA 9 SMA Negeri 1 Sungguminasa sebanyak 50 orang siswa. Sampel diambil dengan teknik random sampling. Instrumen penelitian berupa tes kemampuan berpikir kritis untuk mengukur kemampuan berpikir kritis dan tes hasil belajar untuk mengukur hasil belajar biologi siswa pada materi sistem ekskresi yang berbentuk pilihan ganda. Data dianalisis dengan menggunakan statistik deskriptif dan korelasi product moment. Analisis deskriptif menggambarkan terjadi peningkatan dari pretest ke posttest untuk kemampuan berpikir kritis dan hasil belajar peserta didik. Rata-rata pretest untuk kemampuan berpikir kritis 24,10 dan postest 79, sedangkan, rata-rata pretest untuk hasil belajar 29,80 dan posttest 77,28. Uji hipotesis menunjukkan terdapat hubungan positif yang signifikan antara kemampuan berpikir kritis dengan hasil belajar biologi peserta didik dengan nilai korelasi 0,765 .

Kata Kunci: Problem Based Learning, Teknik Mind Mapping, Berpikir Kritis, dan Hasil Belajar.

Abstract: This study aimed to determine the relation between students critical thinking ability and biology learning outcomes. This study was a pre- experimental and correlation reasearch with one group pretest posttest design. The sample of study consisted of one class is a class XI $I_{P A}$ SMAN 1 Sungguminasa as 50 students. Sample was take with a random sampling technique. The research instrument is a critical thinking ability test and learning outcome in biological material (excretory system) with multiple choice shaped. Data were analyzed using descriptive statistics and product moment correlation. Descriptive analysis describes an increase from pretest to posttest for critical thinking skills and student learning outcomes. The average pretest for critical thinking skills is 24.10 and posttest is 79, whereas, the average pretest for learning outcomes is 29.80 and posttest is 77.28 . The result of hypothesis analysis indicated there was significant positive correlation between critical thingking ability and students' result in learning Biology with correelation value 0,765.

Keyword: Problem Based Learning, Mind Mapping Technique, Critical Thinking, Learning Outcomes.

*) Correspondence Author: saparuddin@unm.ac.id 


\section{PENDAHULUAN}

Pendidikan memilik peran yang sangat vital terhadap kemajuan suatu bangsa. Sebagai negara berkembang, pendidikan di Indonesia harus menjadi prioritas. Kesiapan sumberdaya ditentukan mulai dari bangku sekolah. Pendidikan merupakan suatu sarana yang diharapkan mampu mendidik dan mentransformasikan sumber daya manusia yang bertakwa kepada Tuhan Yang Maha Esa, berkualitas, memiliki skill, dan berbudi pekerti yang luhur. Pendidikan merupakan elemen yang sangat penting untuk menciptakan sumber daya yang berkualitas, cerdas, damai, terbuka, demokratis dan mampu bersaing serta dapat meningkatkan kesejahteraan semua warga Negara Indonesia. Indonesia diharapkan dapat menghadapi berbagai perubahan dan tantangan globalisasi yang sedang dan akan terjadi melalui sumber daya manusia yang bermutu. Oleh karena itu program pendidikan hendaknya senantiasa ditinjau dan diperbaiki (Sanjaya, 2012).

Indonesia diprediksi memiliki bonus demografi pada tahun 2045, dimana pada tahun tersebut mayoritas warga negara berada pada rentang usia produktif. Bonus demografi akan berdampak postif terhadap perkembangan negara jika dipersiapkan dengan baik. Salah satu upaya dalam mempersiapkannya adalah dimulai dari sekolah. Sekolah harus mampu mengintegrasikan kebutuhan dunia kerja dengan pola pendidikan yang diterapkan. Pada abad 21, setidaknya terdapat empat kompetensi yang diharapkan dimiliki oleh siswa dan dibutuhkan dalam dunia kerja yaitu keterampilan berpikir kritis, kreativitas, kemampuan bekerjasama dan keterampilan komunikasi. Maka dari itu, sebagai pendidik, guru hendaknya mampu memilih model maupun metode pembelajaran yang berorientasi pada kecakapan abad 21.

Hasil observasi di sekolah (SMA Negeri 1 Sungguminasa), menunjukkan bahwa proses pembelajaran yang diterapkan guru di sekolah cenderung berorientasi pada penuntasan kurikulum dan pencapaian nilai KKM. Penyajian materi hanya berupa penyampaian konsep-konsep yang tertulis pada buku paket pegangan siswa. Kemampuan koognitif yang dilatihkan pada siswa hanya seputar kemampuan mengingat dan memahami. Hal ini terbukti dengan hasil belajar siswa yang terbatas pada nilai KKM yakni $\leq 65$. Kemampuan berpikir kritis siswa rendah dengan melihat hasil tes kemampuan berpikir kritis yang dihubungkan dengan kehidupan nyata yang diberikan. Oleh karena itu perlu ada penerapan model pembelajaran yang berorientasi pada pencapaian kemampuan berpikir kritis dan kemampuan siswa dalam mengaitkan antara kehidupan nyata dengan konsep yang dipelajari.

Model pembelajaran Problem Based Learning (PBL) adalah model pembelajaran yang menghadapkan siswa pada suatu masalah pada awal pembelajaran dan merupakan salah satu model pembelajaran inovatif yang dapat memberikan kondisi belajar aktif bagi siswa. Prinsip PBL ditekankan untuk memperbaiki cara belajar dengan tujuan untuk menguatkan konsep dalam situasi nyata, mengembangkan keterampilan berpikir tingkat tinggi, keterampilan memecahkan masalah, meningkatkan keaktifan belajar siswa, mengembagkan keterampilan membuat keputusan, menggali informasi, meningkatkan percaya diri, tanggung jawab, kerjasama dan komunikasi.

Problem based learning merupakan suatu model pembelajaran yang dikembangkan dari teori belajar konstruktivisme. Adapun tujuan PBL menurut Rusman (2010) yaitu penguasaan isi belajar dari disiplin heuristik dan pengembangan keterampilan pemecahan masalah. PBL juga berhubungan dengan belajar tentang kehidupan yang lebih luas (lifewide learning), keterampilan memaknai informasi, kolaborasi dan belajar tim, dan keterampilan berpikir reflektif dan evaluatif. Trianto (2010) menyatakan bahwa tujuan PBL yaitu membantu siswa mengembangkan keterampilan berpikir dan keterampilan mengatasi masalah, belajar peranan orang dewasa yang autentik dan menjadi pemb elajar yang mandiri.

PBL adalah suatu pendekatan pembelajaran yang mengguanakan masalah dunia nyata sebagai suatu konteks bagi peserta didik untuk belajar tentang cara berpikir kritis dan 
keterampilan pemecahan masalah, serta untuk memperoleh pengetahuan dan konsep yang esensial dari materi pelajaran. Hal ini disebabkan karena PBL merupakan model belajar yang memang dirancang untuk meningkatkan kemampuan-kemampuan itu. Hal ini sesuai dengan pernyataan dan pandangan berbagai ahli. Nurhadi, dkk (2013) mengemukakan bahwa pembelajaran berbasis masalah adalah suatu pendekatan pengajaran yang menggunakan masalah dunia nyata sebagai suatu konteks bagi siswa untuk belajar tentang cara berpikir kritis dan keterampilan pemecahan masalah. Hasting (2011) juga mengemukakan bahwa pembelajaran berdasarkan masalah dapat mengembangkan kemampuan berpikir kritis dan analisis serta menghadapkan siswa pada latihan untuk memecahkan masalah. Selain meningkatkan kemampuan berpikir tingkat tinggi, PBL juga sejalan dengan peningkatan kemampuan kognitif peserta didik.

PBL telah banyak diteliti penerapannya di sekolah, salah satunya adalah Argaw dkk (2016), yang melakukan penelitian penerapan PBL pada mata pelajaran fisika, mereka ingin melihat motivasi dan kemampuan pemecahan masalah siswa setelah diajar dengan menggunakan model PBL. Penelitian yang dilakukan pada 81 siswa ini menunjukan bahwa terdapat perbedaan signifikan antra kelas eksperimen dan control. Kemampuan pemecahan masalah pada kelas eksperimen lebih tinggi dibandingkan kelas control. Insani, A., Ramlawati, R., \& Yunus, S. R. (2019) dalam penelitiannya juga menunjukkan bahwa hasil belajar IPA peserta didik pada model pembelajaran PBL (Problem Based Learning) lebih tinggi dibandingkan dengan nilai hasil belajar IPA pada penerapan pembelajaran konvensional. Terdapat perbedaan hasil belajar antara kelas eksperimen dan kelas kontrol karena kelas eksperimen menggunakan model pembelajaran PBL, dimana dalam pembelajaran dengan model pembelajaran PBL peserta didik dihadapkan pada masalah dalam IPA. Ikman., Hasnawati., \& Rezky, M. F. (2016) dalam penelitiannya membandingkan kemapuan berpikir kritis siswa antara yang diajar dengan model PBL dan kelas konvensional, hasil penelitian menunjukkan bahwa terdapat perbedaan yang signifikan pada $\mathrm{N}$ Gain kedua model tersebut, dimana model PBL lebih tinggi dibandingkan kelas konvensional. Mulyanto dkk (2018) juga melakukan penelitian penerapan model PBL untuk melihat pengaruhnya terhadap hasil belajar dan kemampuan berpikir kritis peserta didik. Penlitian ini melibatkan 153 siswa yang ditempatkan pada kelas eksperimen dan 156 siswa pada kelas control. Hasil penelitian menjukkan terdapat perbedaan yang signifikan hasil belajar dan kemampuan berpikir kritis siswa pada masing-masing kelas. Rata-rata hasil belajar dan kemampuan berpikir kritis siswa pada kelas eksperimen lebih tinggi dibandingkan kelas kontrol.

Pembelajaran berbasis mind mapping, berusaha menggabungkan kedua belahan otak yakni otak kiri yang berhubungan dengan hal yang bersifat logis (seperti belajar) dan otak kanan yang berhubungan dengan keterampilan (aktivitas kreatif) melalui pengumpulan informasi dan menghubungkan informasi tersebut. Kegiatan siswa membuat min mapping tersebut menurut koognitif Bloom termasuk tingkat pemahaman dan penerapan aplikatif. Tingkat pemahaman yang dilakukan siswa adalah menggeneralisasi dan menguraikan konsep yang dimiliki. Tingkat analisis yang dilakukan adalah mengurai dan mengkorelasikan suatu konsep yang dimiliki dan baru ditemukan.

Mind Mapping mampu meningkatkan kemampuan seseorang dalam berimajinasi, mengingat, berkonsentrasi, membuat catatan, meningkatkan minat sekaligus mampu menyelesaikan persoalan. Menurut Michalko dalam Buzan (2009), mind map akan mengaktifkan seluruh otak, membereskan akal dari kekusutan mental, Memungkinkan kita berfokus pada pokok bahasan, membantu menunjukkan hubungan antara bagian-bagian informasi yang saling terpisah, memberi gambaran yang jelas pada keseluruhan dan perincian, memungkinkan kita mengelompokkan konsep dan membandingkannya, dan mensyaratkan kita untuk memusatkan perhatian pada pokok bahasan yang membantu mengalihkan informasi tentangnya dari ingatan jangka pendek ke ingatan jangka panjang. Selain itu melalui teknik mind mapping siswa akan dengan mudah memahami dan mengingat suatu materi pelajaran, hal ini sejalan dengan pendapat 
Mahmuddin (2010) yang mengemukakan bahwa mind mapping akan memudahkan peserta didik dalam penyajian informasi dan mengingat informasi tersebut.

Saat ini, pembelajaran mind mapping telah banyak dikembangkan dan diterapkan di dalam pembelajaran. Penelitian tentang penerapannya juga sudah banyak dilakukan. Astawa (2019) merilis hasil penelitiannya tentang penerapan mind mapping dalam pembelajaran. Peneliti membandingkan minat belajar pada siswa yang diajar dengan metode mind mapping dan diajar secara konvensioanl. Hasil penelitian menunjukkan bahwa minat belajar siswa pada kelas mind mapping lebih tinggi dibandingkan kelas konvensional. Pada tahun 2017, Wibowo mempublikasi hasil penelitiannya tentang penerapan model pembelajaran mind mapping pada siswa kelas 5 SD untuk meningkatkan hasil belajar peserta didik. Hasil penelitian menunjukkan bahwa terjadi peningkatan hasil belajar peserta didik pada setiap siklus.

Berdasarkan uraian di atas maka sangat relevan ketika model problem based learning dipadukan dengan teknik mind mapping. Penerapan model PBL yang dipadukan dengan teknik mind mapping diharapkan akan menjadikan pembelajaran yang bermakna bagi peserta didik. Pembelajaran Problem based learning dengan teknik mind mapping akan melatih siswa dalam memecahkan permasalahan autentik, mengumpulkan, mengorganisasikan serta menghubungkan informasi yang sesuai dengan pemecahan masalah, sehingga pembelajaran ini akan menguatkan kemampuan berpikir kritis siswa yang akan berdampak pula pada hasil belajar koognitif siswa. Maka dari itu, peneliti bermaksud melakukan penelitian penerapan PBL terintegrasi mind mapping untuk mengetahui hubungan antara kemampuan berpikir kritis siswa dengan hasil belajar biologi siswa melalui penerapan model pembelajaran problem based learning yang terintegrasi dengan keknik mind mapping.

\section{METODE}

Penelitian ini menggunakan metode penelitian eksperimen. Penelitian eksperimen merupakan penelitian yang dimaksudkan untuk mengetahui ada tidaknya akibat dari "sesuatu" yangg diberikan pada subjek penelitian. Penelitian ini adalah penelitian pra eksperimen dengan rancangan penelitian adalah pretest-possttest one group design. Populasi dalam penelitian ini adalah seluruh kelas XI IPA SMA Negeri 1 Sungguminasa yakni sebanyak 531 orang.

Sampel dalam penelitian ini ditentukan dengan menggunakan teknik random sampling yang pengambilan sampelnya berdasarkan kelas bukan individu. Sampel dalam penelitian ini adalah kelas XI IPA 9 yang terdiri atas 50 siswa. Variabel bebas dalam penelitian ini yaitu model problem based learning dengan teknik mind mapping sedangkan variabel terikat yaitu hasil belajar biologi siswa dan kemampuan berpikir kritis siswa. Terdapat dua jenis instrumen penelitian yang digunakan, yaitu untuk mengukur kemampuan berpikir kritis siswa, peneliti menggunakan tes essay berdasarkan indikator kemampuan berpikir kritis yang meliputi merumuskan masalah, memberikan argument, melakukan deduksi, melakukan induksi, melakukan evaluasi, serta memutuskan dan melaksanakan. Hasil belajar yang ingin dicapai dalam penelitian ini adalah hasil belajar kognitif siswa dengan menggunakan tes objektif pilihan ganda pada pokok bahasan sistem ekskresi.

Hasil penelitian dianalisis secara bertahap, yaitu: deskripsi data, uji prasyarat, dan uji hipotesis. Uji prasyarat yang dilakukan yaitu uji normalitas sebaran dalam populasi. Uji hipotesis yang digunakan dalam penelitian ini adalah uji korelasi product moment. Untuk menganalisis data dalam penelitian ini digunakan SPSS 20,0 pada taraf signifikansi 0,05. 


\section{HASIL DAN PEMBAHASAN}

1. Hasil

\section{a. Hasil Belajar Peserta Didik}

Hasil belajar peserta didik diukur dengan menggunakan soal pilihan ganda pada pokok bahasan sistem ekskresi. Instrumen hasil belajar dibagikan kepada peserta didik setelah pembelajaran sebanyak empat kali pada materi system ekskresi. Hasil penelitian menunjukkan bahwa hasil belajar peserta didik sebelum dan sesudah diajar dengan menggunakan model pembelajaran $P B L$ terintegrasi mind mapping mengalami peningkatan yang sangat signifikan. Hal ini dapat dilihat pada perbandingan Nilai rata-rata hasil belajar peserta didikn sebelum dan sesudah diajar. Untuk lebih jelasnya dapat dilihat pada Gambar 1.

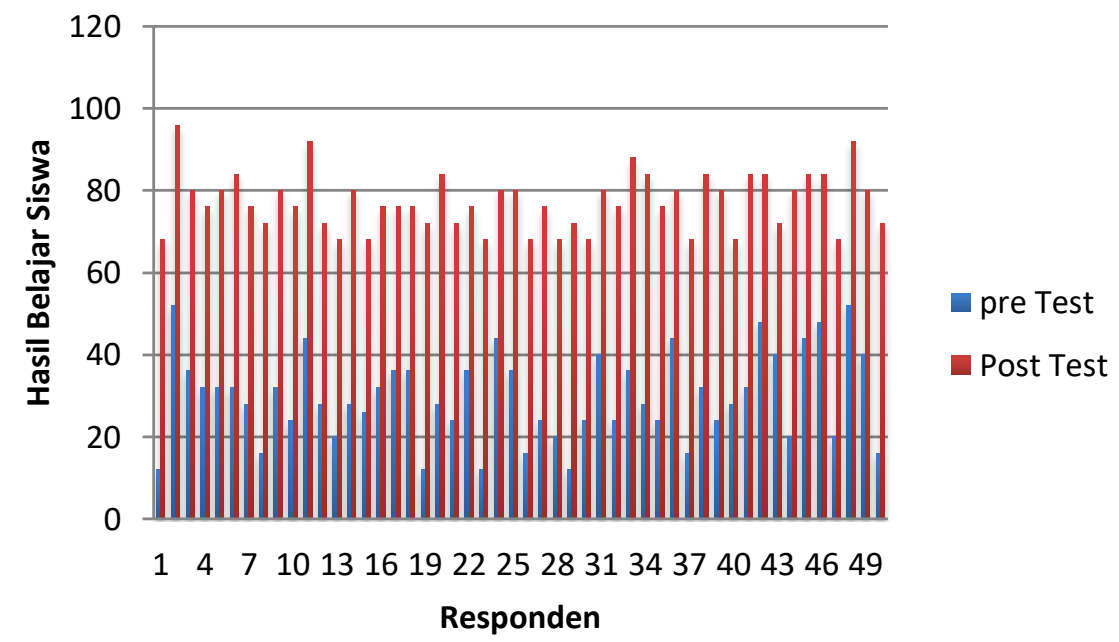

\section{Gambar 1. Hasil Belajar Peserta Didik}

Gambar 1 menunjukkan bahwa dari 50 siswa yang diajarkan dengan model PBL dengan teknik mind mapping semuanya mengalami peningkatan hasil belajar.

\section{b. Hasil Kemampun Berpikir Kritis Peserta Didik}

Penilaian kemampuan berpikir kritis siswa dilakukan sebelum dan sesudah pembelajaran yang menggunakan model PBL dengan teknik mind mapping, diukur dengan menggunakan tes tertulis yang dibuat berdasarkan indikator kemampuan berpikir kritis. Instrumen kemampuan berpikir kritis yang diujikan kepada siswa terdiri atas 5 butir soal. Masing-masing pertanyaan mewakili satu indikator kemampuan berpikir kritis yang diamati. Berdasarkan Hasil penelitian terkait dengan kemampuan berpikir kritis siswa kelas XI IPA 9 pada materi sistem ekskresi sebelum dan sesudah proses pembelajaran dengan menggunakan model pembelajaran Problem Based Leraning dengan Teknik Mind mapping mengalami peningkatan yang signifikan. Untuk lebih jelasnya dapat dilihat pada Gambar 2. 


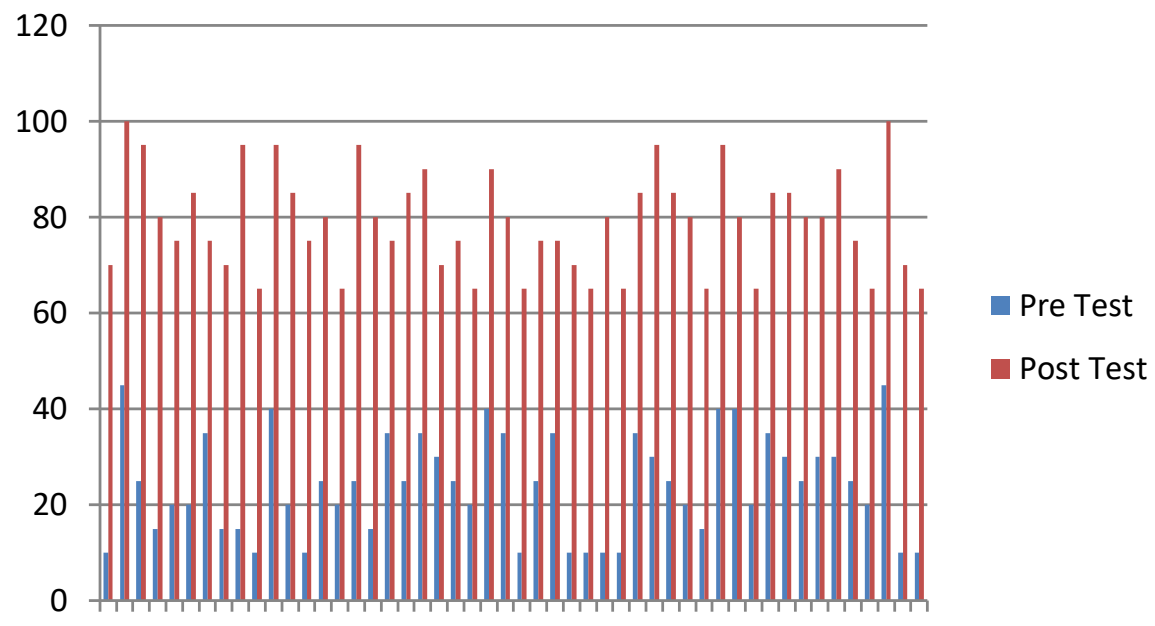

$\begin{array}{lllllllllllllllll}1 & 4 & 7 & 10 & 13 & 16 & 19 & 22 & 25 & 28 & 31 & 34 & 37 & 40 & 43 & 46 & 49\end{array}$

\section{Gambar 2. Hasil Kemampuan Berpikir Kritis Peserta Didik}

Gambar 2 mengungkapkan bahwa dari 50 siswa yang diajarkan dengan model PBL dengan teknik mind mapping semuanya mengalami peningkatan kemampuan berpikir kritis.

\section{c. Analisis Korelasi Hasil Belajar dan Kemampuan Berpikir Kritis Peserta Didik}

Berdasarkan hasil penelitian yang telah dilakukan terlihat adanya korelasi yang positif antara hasil belajar dengan kemampuan berpikir kritis siswa, dimana nilai korelasinya adalah 0,765 dan jika dikonsultasi pada tabel klasifikasi kuat lemahnya hubungan, maka hubungan diantara keduanya berada pada interval sangat kuat. Untuk melihat nilai korelasi antara hasil belajar dengan kemampuan berpikir kritis siswa dapat dilihat pada Tabel 1.

Tabel 1. Nilai Korelasi Antara Hasil Belajar Kognitif Dengan Kemampuan Berpikir Kritis Peserta Didik

\begin{tabular}{cccc}
\hline Nilai Korelasi & Sig Hitung & $\alpha$ & Kategori \\
\hline 0,765 & 0,000 & 0,05 & Sangat Kuat \\
\hline
\end{tabular}

Tabel 1 menunjukkan bahwa nilai $r$ hitung adalah 0,765 dengan nilai sig hitung $0,000<$ sig $a$ 0,05 yang berarti bahwa $\mathrm{H}_{0}$ ditolak. Hal ini menunjukkan bahwa terdapat hubungan positif yang signifikan antara kemampuan berpikir kritis dan hasil belajar siswa. Nilai korelasi kemudian dikonsultasikan dengan pengkategorian hubungan kedua variabel yang diamati. Hasilnya menunjukkan bahwa hubungan antara kemampuan berpikir kritis siswa dan hasil belajar siswa berada pada interval sangat kuat.

\section{Pembahasan}

Berdasarkan hasil penelitian dan analisis data yang telah dilakukan oleh peneliti menunjukkan adanya korelasi positif yang signifikan antara hasil belajar kognitif dengan kemampuan berpikir kritis siswa kelas XI IPA 9 yang diajar dengan menggunakan model pembelajaran PBL dengan teknik mind mapping pada materi sistem ekskresi di SMA Negeri 1 Sungguminasa. Nilai korelasi yang diperoleh berada pada kategori sangat kuat yang artinya bahwa siswa yang memiliki kemampuan kognitif akan diiringi oleh kemampuan berpikir kritis. 
Berpikir kritis adalah kemampuan dalam membuat penilaian terhadap satu atau lebih pernyataan dan membuat keputusan yang objektif berdasarkan pada pertimbangan dan fakta yang mendukung. Berpikir kritis merupakan hal penting dan mendasar untuk semua ilmu pengetahuan, termasuk psikologi. Dengan berpikir kritis, kita dapat membedakan psikologi yang sebenarnya (ilmiah) dari ulasan masalah psikologi tetapi tidak ilmiah. Indikator kemampuan berpikir kritis di atas erat kaitannya dengan hasil belajar kognitif yang melibatkan kemampuan siswa dalam mengingat, memahami, mengaplikasikan, menganalisis, mensintesis dan mengevaluasi sehingga antara kemapuan kognitif dengan berpikir kritis saling berhubungan, apalagi dalam proses pembelajarnnya menggunakan model yang tepat seperti model pembelajaran $P B L$ dengan teknik mind mapping yang dalam proses pelaksanaannya memberikan peluang yang besar kepada siswa untuk berpikir dalam menyelesaikan masalah. Penggunaan model PBL dengan integrasi mind map dapat meningkatkan kemampuan berpikir kritis dan hasil belajar siswa. Ini dapat dilihat dengan kelebihan pada penggunaan teknik mind map yaitu memudahkan peserta didik melihat gambaran dari keseluruhan materi serta membantu peserta didik untuk berpikir mengatur, mengingat, membandingkan dan membuat hubungan dari materi sistem ekskresi secara menyeluruh. Sehingga dengan menggunakan model PBL yang terintegrasi langsung dengan main map dapat memberikan perubahan perkembangan kemampuan berpikir kritis dan hasil belajar siswa.

Hasil penelitian ini didukung oleh penelitian yang dilakukan oleh Ismail (2011), menyatakan bahwa ada hubungan yang positif antara kemampuan kognitif dengan kemampuan berpikir kritis dan kreatif siswa dalam menjabarkan suatu materi ke dalam penjelasan yang lebih mudah dipahami dan dimengerti oleh peserta didik. Hal yang sama diungkapkan oleh Palluvi (2010) yang menyatakan bahwa antara hasil belajar kognitif dengan kemampuan berpikir kritis tidak dapat dipisahkan karena keduannya mengandalkan kemapuan berpikir peserta didik untuk menyelesaikan masalah. Hasil penelitian (Wulandari, 2011) mengungkapkan bahwa terdapat perbedaan yang signifikan antara hasil belajar kelompok mahasiswa yang diajar dengan metode PBL dibandingkan dengan kelompok mahasiswa yang diajar dengan metode konvensional; diperoleh hasil, bahwa rata-rata hasil belajar kelompok mahasiswa yang diajar dengan metode PBL lebih tinggi daripada rata-rata hasil belajar kelompok mahasiswa yang diajar dengan metode konvensional. Secara statistik dapat dinyatakan terdapat pengaruh metode pembelajaran terhadap hasil belajar. Menurut Reta (2012) Setting pembelajaran berbasis masalah yang dilaksanakan dalam kelompok kelompok kecil akan memungkinkan siswa untuk berhadapan dengan kompleksitas pendapat dengan tingkat perbedaan yang tinggi.

Selain model PBL, teknik mind mapping juga berpengaruh terhadap pencapaian hasil belajar siswa. Menurut Akinoglu, (2007) menyatakan bahwa penggunaan teknik mencatat peta pikiran dapat meningkatkan pemahaman siswa terhadap konsep materi pembelajaran, mengatasi kesalah pahaman konsep, dapat meningkatkan prestasi belajar dan sikap belajar siswa. Hal ini sejalan dengan penelitian yang dilakukan oleh Silaban (2012), yang mengungkapkan bahwa Pembelajaran advance organizer dengan mind mapping berpengaruh secara signifikan terhadap hasil belajar siswa. Tingginya kreativitas siswa dalam model pembelajaran advance organizer dengan mind mapping disebabkan mind mapping mampu menghubungkan ide baru dan unik dengan ide yang sudah ada. Sehingga menimbulkan adanya tindakan spesifik yang dilakukan oleh siswa. Melalui penggunaan warna dan simbol-simbol menarik yang akan menciptakan suatu pemetaan yang baru dan berbeda yang membantu daya ingat siswa dalam menyimpan informasi pelajaran. 


\section{KESIMPULAN}

Berdasarkan hasil penelitian dapat disimpulkan bahwa hasil belajar dan kemampuan berpikir kritis peserta didik terdapat hubungan positif yang signifikan setelah diajar dengan menggunakan model pembelajaran problem based learning terintegrasi dengan Teknik mind mapping.

\section{DAFTAR PUSTAKA}

Akinoglu, O. \& Tandagon , R. O. 2007. The Effects of Problem-Based Active Learning in Science Education on Students Academic Achievement, Attitude and Concept Learning. Eurasia Journal of Mathematics, Science \& Technology Education, 2007, 3(1), 71-81.

Argaw, A. S., Haile, B. B., Ayalew. B. T., \& Kuma, S. G. (2016). The Effect of Problem Based Learning (PBL) Instruction on Students' Motivation and Problem Solving Skills of Physics. Eurasia Journal of Mathematics Science and Technology Education, Vol. 13 (3), pp. 857-871. doi 10.12973/eurasia.2017.00647a.

Astawa, D. N. W. (2019). Influence of Mind Mapping Method Implementation on Learning Results Social Science is Required from Students Interest. International Research Journal of Management, IT \& Social Sciences, Vol. 6 (3), pp. 94-100.

Buzan, Tony. 2009. Buku Pintar: Mind Map. Gramedia Pustaka Utama: Jakarta.

Hastings, D. 2011. Case Study Problem Based Learning and the Active Classroom (Online), http://www.cstudies.ubc.ca/facdev/services/newsletter/index/html, diakses 12 April 2012).

Ibrahim, M. 2000. Pembelajaran Kooperatif. Surabaya: Unesa University Press.

Ikman., Hasnawati., \& Rezky, M. F. (2016). Effect Of Problem Based Learning (Pbl) Models Of Critical Thinking Ability Students On The Early Mathematics Ability. International Journal of Education and Research, Vol. 4 (7), pp. 361-374.

Insani, A., Ramlawati, R., \& Yunus, S. R. (2019). Pengaruh Model Pembelajaran PBL (Problem Based Learning) Terhadap Motivasi Dan Hasil Belajar Ipa Peserta Didik Kelas Vii Smp Negeri 5 Pallangga Kab. Gowa (Studi Pada Materi Pokok Pencemaran Lingkungan). Jurnal IPA Terpadu, 2(1).

Ismail. 2011. Penerapan Model Pembelajaran Inquari dan PBL yang Terintegrasi dengan STD Dalam Mengukur Hasil Belajar Kognitif, Afektif, dan Psikomotoirk Siswa. Tesis UM Malang. Malang

Mahmuddin. 2010. Artikel: Pembelajaran Berbasis Peta Pikiran. Diakses pada tanggal 21 september 2010.

Mulyanto, H., Gunarhadi., \& Indriayu, M. (2018). The Effect of Problem Based Learning Model on Student Mathematics Learning Outcomes Viewed from Critical Thinking Skills. International Journal of Educational Research Review, Vol. 3 (2), pp. 37-45.

Nurhadi, Yasin, B., \& Senduk, A.G. 2013. Pembelajaran Kontekstual (Contextual Teaching and Learning) dan Penerapannya dalam KBK. Malang: Universitas Negeri Malang.

Palluvi. 2010. Analisis Kemampuan Berfikir dan Belajar Peserta Didik. PT. Rosdakarya. Bandung

Reta, I Ketut. 2012. Pengaruh Model Pembelajaran Berbasis Masalah terhadap Keterampilan Berpikir Kritis Ditinjau dari Sudut gaya Kognitif. Artikel. Tidak diterbitkan. Program Pasca Sarjana Universitas Pendidikan Ganesha.

Ristiasari, T., Priyono, B,. Sukaesih, S. jurnal: Model Pembelajaran Problem Solving Dengan Mind Mapping Terhadap Kemampuan Berpikir Kritis Siswa. Jurnal Biologi Education. 1(3) (2012).

Rusman. 2010. Model-Model Pembelajaran Mengembangkan Profesionalisme Guru. Jakarta: Raja Grafindo Persada.

Sanjaya, Wina. 2012. Strategi Pembelajaran Berorientasi Standar Proses Pendidikan. Kencana: Jakarta.

Silaban, R. 2012. Pengaruh Media Mind Mapping Terhadap Kreativitas dan Hasil Belajar Kimia Siswa 
SMA pada Pembelajaran Menggunakan Advance Organizer. Artikel. FMIPA Universitas Negeri Medan

Sugiyono. 2010. Metode penelitian pendidikan: pendekatan kuantitatif, kualitatif, dan R\&D. Bandung: Alfabeta.

Suprijono, A. 2011. Model-Model Pembelajaran Inofatif Berorientasi Konstruktivistik. Prestasi Pustaka Publisher: Jakarta.

Trianto. 2009. Mendesain Model Pembelajaran Inovatif Progresif: Konsep, Landasan, dan Implementasinya pada Kurikulum Tingkat Satuan Pendidikan (KTSP). Jakarta: Kencana Prenada Media Group.

Wibowo, N. (2017). An Application Of Mind Mapping Teaching Model To Enhance Natural Science Learning Achievement In The Fifth Graders In The First Semester At Sd N 4 Kaliuntu. International Journal of Elementary Education, Vol.1 (4) pp. 250- 254.

Wulandari. 2011. Pengembangan Perangkat Pembelajaran Berbasis PBL dan Inquary. Tesis. UPI Bandung. Bandung.

\section{Saparuddin}

Dosen Program Studi Pendidikan Biologi Universitas Negeri Makassar, aktif melakukan penelitian pada bidang pendidikan biologi, alamat email: saparuddin@unm.ac.id

\section{Dian Dwi Putri Ulan Sari Patongai}

Dosen Program Studi Pendidikan Biologi Universitas Negeri Makassar, aktif melakukan penelitian pada bidang pendidikan biologi, alamat email: dianputriulan@unm.ac.id

\section{Sahribulan}

Dosen Program Studi Biologi Universitas Negeri Makassar, aktif melakukan penelitian pada bidang biologi, alamat email: sahribulan@unm.ac.id 